THE IDEAL UNIVERSITY ADMINISTRATION

THE recent controversy in Syracuse University is one that is of far more importance to the educational interests of this country than a mere quarrel between two individuals. It is a symptom of a disease which to some extent is common in many universities, that is, the government of a university by a single autocrat, supported in power by a body of absentee trustees who are not educational experts. The time is ripe for a general study of the subject of university administration.

A university is primarily a congregation of students and teachers. The corporation responsible for the administration of the university may or may not be constituted wholly or partially of either students or teachers. The earliest university in Europe, that of Bologna, Italy, founded in the year 1119, was a corporation of students. The University of Paris, founded in 1200 , was a corporation of teachers. Given a body of students of legal age, they might under our laws form a corporation, and it might hire a body of teachers, frame a set of by-laws, erect and furnish buildings and equipment, and so form a university. Or another body composed exclusively of teachers might form an organization, elect themselves as officers, issue stock, rent or erect buildings and furnish them, and advertise for students just as a mercantile house advertises for customers. A third method of making a university would be for a single rich man to furnish money, form a corporation with four dummy stockholders, giving them one share of stock each, erect buildings, provide the necessary equipment, hire teachers, advertise for students, and begin the business of furnishing education in exchange for tuition fees.

These three different corporations might each organize and carry on a university of the highest rank. These three uni- versities may differ in many things; in age and reputation, in wealth, in numbers of professors and students, in social standing and in fame in athletics, in methods of teaching and in number of subjects taught, in systems of government and administration. One may have a magnificent campus and marble palaces, another no campus at all, but a lot of rented brick buildings in a city block, converted from old residences. They may differ in all these things, but in one thing they must agree, the possession of a corps of professors of the first rank. Given such a corps of professors and the students will come as a matter of course. The real university is the body of professors and students. The real work of the university is teaching. The buildings, the equipment, the system of administration, are the possessions, the appendages of the university, not the university itself. As the body is more than the raiment, as the inhabitants of a house are more than the house, as a man is more than his possessions, so is a university more than its mere equipment.

Given a real university, a body of capable, cultured gentlemen, able and willing to teach, a body of carefully selected students, able and willing to learn, a roof to cover them, the necessary equipment of furniture, apparatus and other material that modern methods of teaching require, what else does a university need to enable it to carry on its work?

First, money to keep it from going into bankruptcy. This may be furnished by the state, as is done in the west. The students may contribute a great deal of it, as in most eastern colleges. The professors contribute some by working for small salaries, getting the remainder of their income from interest on their investments or from doing outside work, and some is presented in the shape of contributions or legacies from philanthropic citi- 
zens. The money is a mere detail. Good beggars may be hired on commission or salary to get enough of it to make up the annual deficits.

The next thing is a proper organization of departments. This the professors themselves, being educational experts, can easily provide.

Then there has to be provided a system of government. This will depend at first on the ideas of the originators of the university. We have assumed three universities, one started by students, one by teachers and one by a single rich man. They may all eventually by evolution reach the same best governmental system, or by degeneration the worst. The fittest may survive at last, but the unfit survives a long time. The United States has a splendid system of government, divided into legislative, executive and judicial departments, with mutual checks on one another, the result of the brains of Hamilton, Jefferson, Franklin and Washington. Old New England had an excellent system in its town meetings, but many of our states and cities are now suffering from bad government, the results of boss rule. So universities have not all reached the best type of government, and the existing type varies all the way from that of the chaos of mob rule to the rule of a czar. Mob rule is unstable, and never lasts very long. The boss soon appears and the rest of the mob become his puppets. The czar system is stable; it may last a thousand years, but it has fallen even in Persia, it is on the verge of falling in Russia, and it may fall within ten years in Turkey. The rule of the boss and that of the czar are not very different in results, although the czar rules by military force and the boss by the power of money.

The best system for a university is neither the boss nor the czar system, but the democratic system; not mob rule, but a carefully planned system of representative government, of which that of the United States is a model. It is founded on the principles of the Magna Charta and the Declaration of Independence. It involves the privileges of free speech, freedom of the press and trial by a jury of one's peers.

The object of a system of government, it has been said, is "to get things done." In organizing a good system of: government there should be a carefully prepared list of the different things that are to be done and the best way of doing each should be considered. A mere suggestion of such a list is the following:

1. Determine the general policy of the university as to what departments of education it shall engage in.

2. Determine who shall have the appointing power of the executive officers of the government and who shall appoint professors and instructors.

3. Who shall be charged with the responsibility of raising money and who with the responsibility of spending it?

4. Who shall frame the constitution and by-laws and how and by whom shall they be amended?

5. The government of a university being like that of a nation, legislative, executive and judicial, where shall these different governmental powers be placed?

6. What procedure shall be followed in case any one has to make a complaint against a professor or instructor or other person holding office?

7. How shall a jury be constituted for his trial?

8. If the university is composed of several colleges, shall the general. government of the university be managed by representatives from the colleges, or shall each college exercise only such power as may be allowed it from time to time by a central governing body or by an autocrat? 
9. What rules shall be enacted concerning the discipline of students and who shall be entrusted with the enforcing of these rules?

10. What provision, if any, shall be made for calling in outside experts to advise in regard to improvements in educational methods, or what facilities shall be given to the professors to travel and study such methods?

The above list is not intended as a complete list, but is merely a suggestion as to the kind of questions that may arise in forming a university government.

The following is suggested as a form of organization which will best secure the desired result:

A board of trustees, the legal corporation, responsible for the financial management and for the enactment of broad legislation as to matters of general policy. It should contain men of wealth and social standing, to give it the prestige that such men can bring; men skilled in business and the law, to look after its invested funds; experienced educators, whose counsel may be valuable on matters of educational policy; representatives of each of the learned professions that has a college in the university; and representatives of the alumni of each college. Such a body of men under a proper system of government will not need to meet oftener than twice a year except in cases of emergency, nor will it need to take any active part in the details of management, but it would establish a set of rules delegating specific powers to another body of men better qualified than the trustees are to exercise them.

Such other body is a university senate or council, and it might be composed of, say, three trustees, who are willing to devote some time to university matters, of the deans of each college, ex-officio, of one professor from each college, elected for a definite period by its faculty, and of one alumnus of each college, not a trustee or holding any other position in the university, elected by the alumni association of each college.

This university council should be granted all powers not especially reserved by the board of trustees, and it may delegate such minor powers as it sees fit to the several deans or faculties.

The president or chancellor of the university should properly be elected by the trustees. He should represent the university on all public occasions. If he is an orator and money-getter, all the better; but whatever he is, it is not wise to give him autocratic power over the faculties nor over the council.

There might be a vice-chancellor, elected by the trustees on nomination of the council. It should be his duty to preside over the council, and to have a general oversight over educational matters, and he therefore should be an experienced educator.

Given two such bodies, each composed of strong men, and they could be trusted to discover the best system of university government and to frame it in a constitution and by-laws. Under such a government strong men could be obtained to fill the professors' chairs; they would be secure in their positions as long as they did their duty, and such a disgraceful proceeding as the one that has just taken place at Syracuse would be impossible.

$$
\begin{gathered}
601 \text { Comstock Ave., } \\
\text { Syracuse, N. Y., } \\
\text { June 9, } 1908
\end{gathered}
$$

\section{THE INTERNATIONAL CATALOGUE OF SCIENTIFIC LITERATURE}

IN a paper entitled "Cooperation in Scientific Bibliography" which appeared in ScIENCE, April 3, 1908, no mention was made of the work being done by the International Catalogue of Scientific Literature. As the 